\title{
Pembuatan Media Pembelajaran Dasar Bahasa Korea Menggunakan AndEngine Berbasis Android
}

\author{
Ramos Somya ${ }^{1}$, Valenciana Tjahjono ${ }^{2}$ \\ Fakultas Teknologi Informasi, Universitas Kristen Satya Wacana \\ J1. Diponegoro 52-60, Salatiga 50711, Jawa Tengah \\ E-mail: 1'ramos.somya@staff.uksw.edu, ${ }^{2}$ valenciana.tjahjono@gmail.com
}

Masuk: 14 September 2015; Direvisi: 17 September 2015; 30 September 2015; Diterima: 30 September 2015

\begin{abstract}
Korean has now become one foreign language preferred by the Indonesians to learn. This is the impact of the entry of Hallyu (Korean Wave) in Indonesia. However, existing Korean language learning media are less not interactive because there are limited facilities such as books when compared with mobile application that has attractive design and audio facility. Based on the problem, a basic Korean language learning applications using AndEngine on Android platform is developed. This application uses AndEngine library and uses an accelerometer extension that belongs to AndEngine. With this application, users can learn Korean letters and how to read it in a more interesting method because there is a mini game in this application.
\end{abstract}

Keywords: Korean language, AndEngine, Android.

\begin{abstract}
Abstrak. Bahasa Korea saat ini menjadi salah satu bahasa asing yang diminati untuk dipelajari oleh masyarakat Indonesia. Hal ini merupakan dampak dari masuknya Hallyu (Korean Wave) di Indonesia. Namun saat ini media pembelajaran bahasa Korea masih kurang interaktif karena keterbatasan sarana misalnya buku, dibandingkan dengan aplikasi mobile yang memiliki desain yang menarik dan fasilitas audio. Berdasarkan masalah tersebut dibuat aplikasi pembelajaran dasar bahasa Korea menggunakan AndEngine berbasis Android. Dalam pengembangan aplikasi ini digunakan library AndEngine dan memanfaatkan ekstensi accelerometer yang dimiliki oleh AndEngine. Dengan adanya aplikasi ini, para pengguna bisa belajar berbagai macam huruf bahasa Korea dan cara membacanya dengan lebih menyenangkan, karena aplikasi juga dilengkapi dengan mini game.
\end{abstract}

Kata Kunci: Bahasa Korea, AndEngine, Android.

\section{Pendahuluan}

Bahasa Korea di Indonesia beberapa tahun lalu bukanlah sesuatu yang menarik, namun saat ini bahasa Korea memiliki peran penting dalam pergaulan internasional. Hal ini dapat dilihat dengan seiiring gencarnya serangan ekonomi dan Hallyu (Korean Wave) membuat bahasa Korea menjadi bahasa yang banyak diminati dan diperhitungkan (Anam, dkk., 2013). Misalnya lima tahun lalu, serial Korea yang ditayangkan di stasiun televisi Indonesia masih sedikit, jumlahnya hanya dua hingga tiga serial yang ditayangkan dalam jangka satu tahun, serta belum ada boyband atau girlband Korea yang konser di Indonesia. Kemudian mulai tahun 2010 hingga sekarang, serial dan lagu Korea mulai diminati oleh banyak orang. Stasiun-stasiun televisi di Indonesia mulai sering menayangkan serial Korea, seperti Boys Before Flower, City Hunter, 49 Days, Dream High, dan masih banyak lagi. Boyband dan girlband Korea juga mulai melakukan promosi di Indonesia dengan cara mengadakan konser atau acara greet and meet.

Untuk mengikuti Korean Wave di Indonesia tersebut, masyarakat mulai mempelajari bahasa Korea. Namun, media pembelajaran bahasa Korea saat ini masih kurang interaktif sehingga kurang menarik perhatian dari masyarakat. Hal ini dikarenakan keterbatasan sarana dalam pembelajaran bahasa Korea melalui buku membuat sebagian besar masyarakat peminat bahasa Korea menjadi sulit untuk mempelajari bahasa Korea. Pembelajaran melalui buku dinilai 
kurang interaktif karena tidak ada fasilitas suara cara pelafalan bahasa Korea. Pembelajaran lain didapatkan melalui jalur pendidikan di lembaga pendidikan, seperti penelitian yang dilakukan oleh Ana Maghfiroh yang meneliti tentang maraknya masyarakat di daerah Ponorogo dalam mengikuti pelatihan bahasa Korea di lembaga pendidikan Sarangheo. Namun pendidikan di lembaga pendidikan ini masih juga masih mengandalkan materi dari buku dan harus mengeluarkan biaya dan waktu untuk mengikuti pelatihan tersebut (Maghfiroh, 2013). Pembelajaran dengan menggunakan aplikasi mobile dinilai lebih interaktif dan menyenangkan untuk pembelajaran bahasa Korea, karena didukung dengan desain yang menarik dan suara cara pelafalan bahasa Korea (Arifina, 2011).

Untuk mengikuti perkembangan tersebut, dibuatlah suatu alat bantu yang dapat digunakan untuk membantu dalam mempelajari bahasa Korea, yaitu penggabungan antara pelajaran dasar bahasa Korea dan program aplikasi pada platform Android. Aplikasi yang akan dibuat berisi tentang huruf-huruf Korea (Hangeul), Batchim, dan Batchim Gabungan. Platform yang digunakan dalam pembuatan aplikasi ini adalah Android. Pembuatan aplikasi ini juga menggunakan ekstensi accelerometer yang dimiliki oleh library AndEngine.

\section{Kajian Pustaka \\ 2.1. Penelitian Sebelumnya}

Terdapat empat penelitian sebelumnya yang membahas dan meneliti tentang pembelajaran bahasa Korea. Penelitian pertama oleh Ardiansyah \& Na'im (2012) menghasilkan sebuah aplikasi mobile web percakapan bahasa Korea berbasis lokasi menggunakan Foursquare API dengan memanfaatkan geolocation pada smartphone, geolocation, Ruby on Rails framework dan Foursquare. Sistem ini dapat digunakan untuk membantu pengguna dalam mempelajari dan menggunakan percakapan bahasa Korea sesuai tempat di mana pengguna berada serta dapat melakukan check in pada venue tertentu melalui akun Foursquare. Dalam aplikasi ini juga terdapat basic things untuk mengenalkan dasar-dasar dalam bahasa Korea seperti angka, tanggal, waktu, memberi salam, dan special occasion.

Penelitian kedua oleh Septiawan \& Setiadi (2013), membahas pembuatan multimedia interaktif yang digunakan untuk pengenalan huruf Hangeul Korea. Hasil penelitian ini adalah aplikasi multimedia sebagai media pembelajaran Bahasa Korea Dasar tentang pengenalan huruf Hangeul khususnya cara penuliasan dan cara pengucapan bagi siswa kursus Bahasa Korea kelas dasar. Aplikasi telah diuji coba menggunakan black box testing dan alpha testing. Berdasarkan hasil uji coba tersebut dapat disimpulkan bahwa aplikasi ini dapat membantu proses pembelajaran secara mandiri pada siswa dan dapat digunakan sebagai alat bantu guru yang dapat menunjang pembelajaran Bahasa Korea di kelas.

Penelitian ketiga oleh Damarullah, dkk. (2013) membahas pembuatan aplikasi mobile berbasis Android untuk pembelajaran dasar bahasa Korea. Aplikasi yang dihasilkan berfungsi sebagai media pembelajaran (edutainment), dengan menu yang tersedia seperti pengenalan huruf, aturan pengucapan, cara penulisan, serta beberapa contoh kosakata dan kalimat.

Penelitian keempat oleh Maghfiroh (2013) membahas tentang ketertarikan calon tenaga kerja Indonesia untuk menempuh pendidikan di lembaga pendidikan Sarangheo sebelum bekerja di Korea. Penerapan model pembelajaran grammar translation method, audio lingual method, and direct method di lembaga pendidikan Sarangheo ternyata mampu menghantarkan siswanya untuk dapat menguasai bahasa Korea dengan cepat, dan utamanya dapat mempersiapkan siswa untuk dapat mengikuti dan lolos dalam tes (EPS) atau tes khusus untuk bekerja di Korea.

Terdapat perbedaan antara aplikasi pembelajaran dasar bahasa Korea pada penelitian ini dengan penelitian sebelumnya. Penelitian pertama menghasilkan aplikasi web yang digunakan untuk belajar percakapan bahasa Korea berdasarkan lokasi pengguna. Pengguna aplikasi ini adalah pengguna yang sudah menguasai dasar bahasa korea seperti huruf Hangeul, Batchim dan Batchim Gabungan. Sedangkan penelitian ini menghasilkan aplikasi mobile yang digunakan oleh pengguna yang akan belajar bahasa Korea pertama kali, yaitu untuk mempelajari dasar bahasa Korea yang meliputi pembelajaran huruf Hangeul, Batchim dan Batchim Gabungan. Penelitian kedua membahas pembuatan multimedia interaktif menggunakan Macromedia Adobe 
Flash CS4 untuk pengenalan huruf Hangeul Korea saja, sedangkan penelitian ini membahas tentang media pembelajaran dasar bahasa Korea yang mencakup pengenalan huruf Hangeul, Batchim dan Batchim Gabungan pada platform Android. Penelitian ketiga menghasilkan aplikasi mobile berbasis Android untuk belajar pengenalan huruf, aturan pengucapan, cara penulisan, serta beberapa contoh kosa kata dan kalimat dengan huruf Hangeul. Sedangkan pada penelitian ini, aplikasi mobile Android yang dihasilkan terdiri dari pembelajaran Huruf Hangeul, Batchim dan Batchim Gabungan serta ditambahkan fitur mini game untuk menambah ketertarikan pengguna dalam menggunakan aplikasi ini. Penelitian keempat membahas tentang observasi yang dilakukan untuk mengetahui alasan ketertarikan masyarakat di daerah Ponorogo untuk belajar bahasa Korea di lembaga pendidikan Sarangheo. Lembaga pendidikan tersebut menggunakan model pembelajaran grammar translation method, audio lingual method, dan direct method. Sedangkan pada penelitian ini, model pembelajaran dasar bahasa Korea menggunakan aplikasi mobile Android, sehingga pengguna dapat belajar dasar bahasa Korea kapan saja dan di mana saja.

\subsection{Bahasa Korea}

Bahasa Korea merupakan salah satu bahasa yang saat ini sedang diminati oleh banyak orang di beberapa Negara, termasuk Indonesia. Sistem penulisan bahasa Korea yang asli, disebut juga Hangeul, merupakan sistem yang silabik dan fonetik. Hangeul diciptakan oleh raja ke empat di masa kerajaan Chosun, Raja Agung Sejong di tahun 1443, hingga diamanatkan pada tahun 1446. Huruf Korea terdiri dari 14 huruf konsonan dan 10 huruf vokal yang digabung untuk membentuk suku kata. Huruf Korea dibagi menjadi empat bagian, yaitu huruf vokal, huruf konsonan, huruf gabungan vokal, dan huruf gabungan konsonan. Pada awal penciptaan huruf ini memang hanya terdiri dari vokal dan konsonan saja. Tetapi kemudian pada perkembangannya ditambahkan lagi huruf gabungan vokal dan huruf gabungan konsonan (Dewi, 2010). Dalam bahasa Korea terdapat banyak struktur kalimat, terutama dalam penulisan huruf menjadi sebuah kata serta pembentukan kata menjadi sebuah kalimat. Struktur kalimat ini terdiri dari beberapa tahap yang dapat dipelajari mulai dari struktur kalimat untuk membentuk kalimat sederhana hingga membentuk kalimat yang lebih rumit. Biasanya struktur kalimat sederhana dipelajari pada bahasa Korea tingkat dasar.

\subsection{Media Pembelajaran}

Media pembelajaran adalah sarana komunikasi dalam bentuk cetak maupun pandangdengar, termasuk teknologi perangkat keras. Oleh karena proses pembelajaran merupakan proses komunikasi dan berlangsung dalam suatu sistem, maka media pembelajaran menempati posisi yang cukup penting sebagai salah satu komponen sistem pembelajaran. Tanpa media, komunikasi tidak akan terjadi dan proses pembelajaran sebagai proses komunikasi juga tidak akan bisa berlangsung secara optimal. Media pembelajaran adalah komponen integral dari sistem pembelajaran (Triyanto, dkk., 2013).

\subsection{Mobile Learning}

Mobile Learning memiliki arti yang berbeda-beda untuk masing-masing komunitas. Beberapa definisi tentang M-learning dapat disebutkan sebagai berikut: M-Learning adalah segala jenis pembelajaran yang mana pembelajar tidak di lokasi yang tetap atau sudah ditentukan, ataupun pembelajaran di mana pembelajar mengambil manfaat dari teknologi mobile. M-Learning merupakan akuisi dari berbagai pengetahuan dan keahlian lewat penggunaan teknologi mobile, di mana saja dan kapan saja, yang menghasilkan perubahan dalam tingkah laku (Sutrisno \& Istiyanto, 2009).

\subsection{Permainan}

Permainan adalah kegiatan yang kompleks yang di dalamnya terdapat peraturan, bermain dan budaya. Sebuah permainan adalah sebuah sistem di mana pemain terlibat dalam konflik buatan. Di sini pemain berinteraksi dengan sistem dan konflik dalam permainan 
merupakan rekayasa atau buatan. Dalam permainan terdapat peraturan yang bertujuan untuk membatasi perilaku pemain dan menentukan permainan (Zamroni, dkk., 2013).

\subsection{AndEngine}

AndEngine adalah game engine 2D OpenGL untuk Android yang bersifat open source untuk pengembangan game 2D di Android. AndEngine ini berupa library tambahan dengan ekstensi .jar yang dapat di-install ke dalam project Android pada program Eclipse. AndEngine memiliki beberapa ekstensi tambahan, seperti: LiveWallpapers, SVGTextureRegion, TexturePacker, MultiTouch, Scripting, dan Accelerometer (Gramlich, 2010).

Ada tujuh komponen penting yang harus ada ketika membangun aplikasi menggunakan AndEngine yaitu Engine, IResolutionPolicy, Camera, Scene, Entity, Texture, dan TextureRegion. Engine mengatur sinkronisasi gambar secara periodik dan memperbaharui scene yang berisi semua konten aplikasi yang sedang dibangun. IResolutionPolicy digunakan untuk mengatur ukuran layar pada AndEngine, yaitu RatioResolutionPolicy yang berfungsi untuk memaksimalkan permukaan layar dengan membatasi ukuran layar dengan rasio tertentu. Yang artinya objek tidak akan terdistorsi karena permukaan layar memiliki ukuran yang maksimal. Camera mendefinisikan sebuah kotak dari sebuah scene yang tergambar di layar. Biasanya ada satu camera pada setiap scene. Camera memiliki subclasses yang memiliki kelebihan fungsi, yaitu BoundCamera dan ZoomCamera. Scene merupakan tempat utama untuk semua objek yang tergambar di layar. Sebuah scene memiliki layers dalam jumlah tertentu yang mengandung sejumlah entity. Entity adalah sebuah objek yang dapat digambarkan, seperti sprite, rectangle, text or lines. Sebuah entity memiliki posisi, rotasi, skala, warna, dan lain sebagainya. Texture adalah sebuah gambar yang memiliki lebar dan tinggi. AndEngine menggabungkan sebuah texture dari beberapa ITextureResources untuk menghemat ruangan memori. TextureRegion mendefinisikan sebuah kotak dari texture (Gramlich, 2010).

\section{Perancangan Sistem}

Perancangan sistem ini mulai dibuat dengan menggunakan UML (Unified Modeling Language) yang terdiri dari use case diagram, activity diagram, dan class diagram. User yang menggunakan aplikasi ini memiliki tiga aktivitas. Aktivitas pertama adalah user dapat melihat daftar materi dan memilih materi yang diinginkan. Aktivitas kedua adalah user dapat melihat isi materi. Aktivitas ketiga adalah user dapat memainkan mini game. Use Case Diagram tersebut dapat dilihat pada Gambar 1.

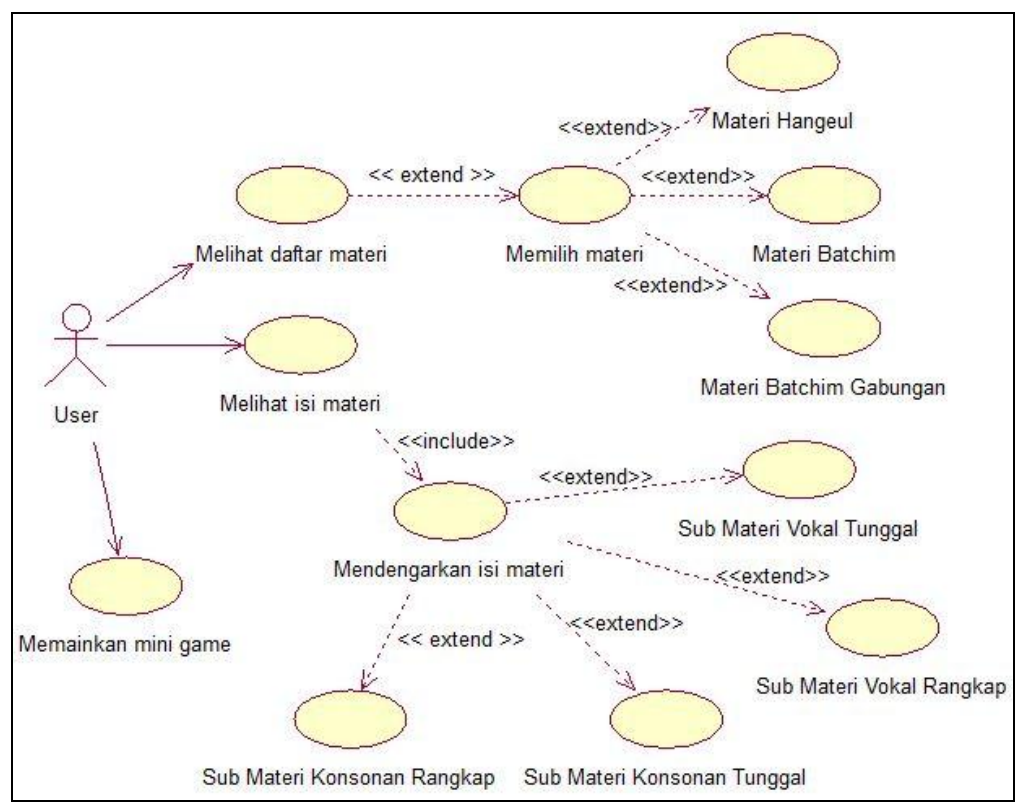

Gambar 1. Use Case Diagram 
Activity diagram pada Gambar 2 menjelaskan bagaimana alur jalannya user menjalankan aplikasi dan memilih materi. Activity diagram pada Gambar 3 menjelaskan alur user memainkan mini game.

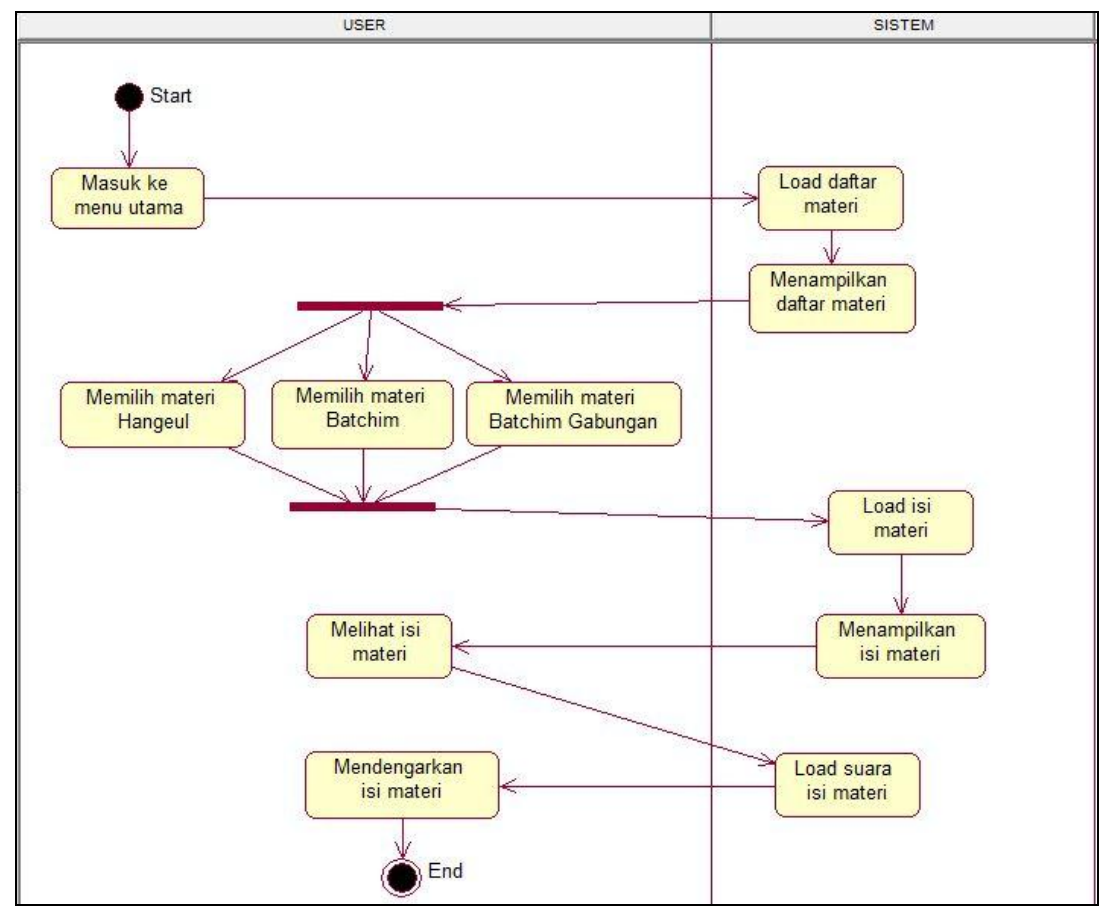

Gambar 2. Activity Diagram Memilih Daftar Materi

Pada saat user menekan tombol play yang ada pada halaman menu, user dapat langsung memainkan mini game tersebut dan setelah selesai user akan mendapatkan nilai atau score. Untuk lebih mudah dipahami, activity diagram memainkan mini game dapat dilihat pada Gambar 3.

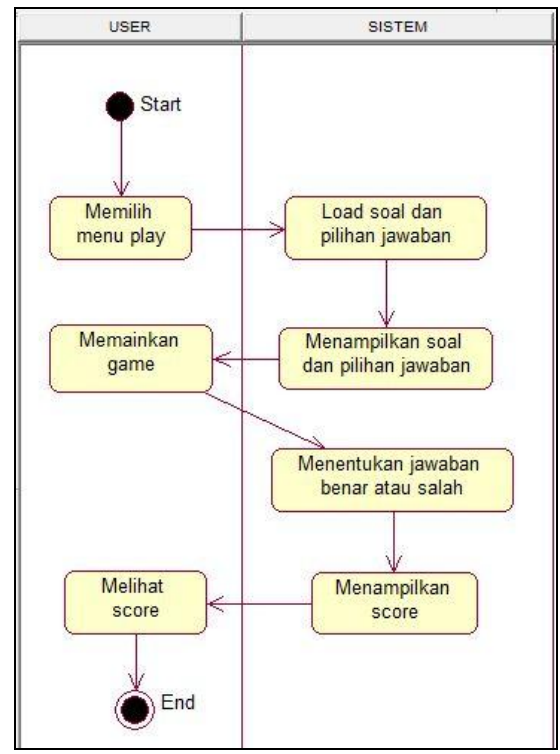

\section{Gambar 3. Activity Diagram Memainkan Mini Game}

Gambar 4 berikut ini merupakan gambaran desain mini game yang dibuat. User memainkan mini game ini dengan menggerakkan device ke kiri dan ke kanan untuk menjawab soal berupa tulisan Hangeul yang diberikan secara acak dan disediakan tiga pilihan jawaban 
berupa cara membaca tulisan Hangeul tersebut di bagian bawah. Obyek lingkaran pada layar akan bergerak mengikuti gerakan device dan akan masuk ke pilihan jawaban yang dipilih. Jika jawaban benar, maka skor akan bertambah. Proses gerakan device ini menggunakan fungsi Accelerometer yang disediakan oleh library AndEngine.

Pada Gambar 5, dapat diketahui bahwa terdapat UtamaUI yang berguna untuk menghubungkan seluruh UI yang ada di aplikasi ini, yaitu MateriHangul, MateriBatchimT, MateriBatchimG, dan MiniGame. MateriHangul memiliki atribut btnIsiMateri yang berfungsi sebagai variabel untuk menampung isi materi Hangeul yaitu vokal tunggal, vokal rangkap, konsonan tunggal, dan konsonan rangkap yang apabila ditekan akan mengeluarkan suara. MateriBatchimT memiliki atribut txtBatchimt yang berfungsi untuk menampung isi materi Batchim yaitu batchim ' $k$ ', batchim' $n$ ', batchim ' $t$ ', batchim ' 1 ', batchim ' $m$ ', batchim ' $p$ ', dan batchim 'ng'. MateriBatchimG memiliki atribut txtBatchimg yang berfungsi untuk menampung isi materi Batchim Gabungan yaitu konsonan depan dan konsonan akhir. MiniGame memiliki atribut txtSoal untuk menampung soal-soal yang dikeluarkan secara acak, txtJawab untuk menampung pilihan jawaban, dan txtScore untuk menampung score yang akan diperoleh user ketika permainan berakhir.

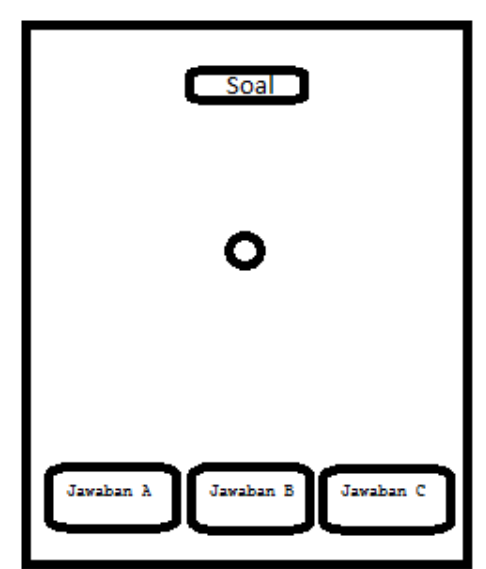

Gambar 4. Desain Mini Game

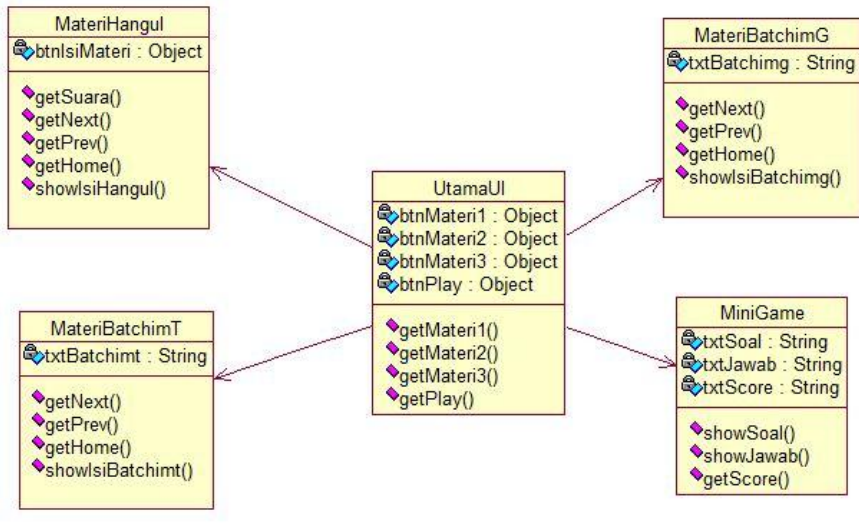

Gambar 5. Class Diagram Sistem

\section{Implementasi dan Pembahasan \\ 4.1. Halaman Utama}

Halaman Utama merupakan halaman interface menu utama. Terdapat menu tiga materi dasar bahasa Korea, yaitu materi Hangeul, materi Batchim, dan materi Batchim Gabungan, serta menu tambahan untuk memainkan mini game yaitu menu Play. Tampilan tersebut dapat dilihat pada Gambar 6. Menu pertama yaitu materi Hangeul, berisi tentang urutan huruf bahasa Korea yang terdiri dari huruf vokal dan huruf konsonan. Pada materi ini terdapat empat sub-materi yaitu Vokal Tunggal, Vokal Rangkap, Konsonan Tunggal, dan Konsonan Rangkap. Vokal tunggal berisi huruf a, ya, eo, yeo, o, yo, u, yu, eu, dan i. Vokal rangkap berisi huruf ae, yae, e, ye, wa, wae, oe, wo, we, wi, dan eui. Konsonan tunggal berisi huruf g/k, n, d/t, r/l, m, b/p, s, $\mathrm{ng}$, c/j, ch, kh, th, ph, dan h. Konsonan rangkap berisi huruf kk, tt, pp, ss, dan jj. Tampilan tersebut dapat dilihat pada Gambar 7.

Huruf-huruf bahasa Korea yang ada di dalam materi merupakan gambar atau texture. Gambar-gambar tersebut telah disimpan ke dalam folder asset yang sudah ada dalam project Android. Untuk menampilkan gambar tersebut di layar, maka dilakukan pemanggilan gambar dengan cara mengarahkan ke folder tersebut. Penjelasan cara menampilkan gambar pada AndEngine tersebut dapat dilihat pada Kode 1. Pada penggalan Kode 1 dapat dilihat bahwa untuk menampilkan gambar pada layar harus menentukan terlebih dahulu berapa gambar yang akan ditampilkan. Misalnya pada halaman materi Vokal Tunggal ada 10 gambar huruf bahasa Korea. Kemudian pemanggilan gambar dilakukan dengan mengarahkan ke folder dimana 
gambar tersebut disimpan yaitu "gfx/vtunggal/1_" dan menyertakan ekstensi gambar yang dipanggil yaitu PNG.

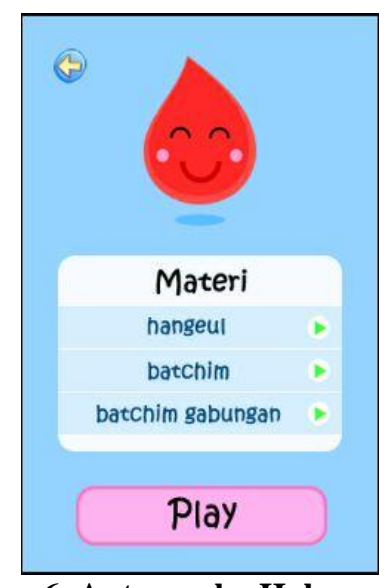

Gambar 6. Antarmuka Halaman Menu

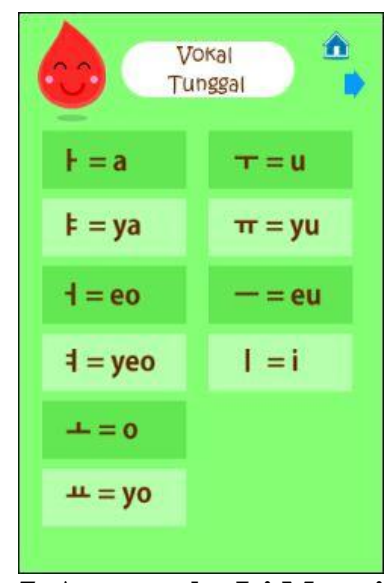

Gambar 7. Antarmuka Isi Materi Hangeul

Pada materi pertama ini, huruf-huruf bahasa Korea tersebut dapat mengeluarkan suara cara pelafalannya dengan cara menekan huruf-huruf tersebut. Suara yang digunakan pada aplikasi ini memiliki ekstensi MP3. File audio yang digunakan pada materi ini telah disimpan pada folder asset seperti halnya file gambar. Penjelasan mengenai pemanggilan file audio tersebut dapat dilihat pada Kode 2. Pada penggalan Kode 2 dapat dilihat bahwa fungsi getSoundManager() digunakan untuk pemanggilan file audio yang ada pada folder " $\mathrm{mfx} / 1$ _". Pemanggilan file audio menyertakan ekstensi file yang dipanggil tersebut yaitu MP3.

Kode 1. Penggalan Kode Program untuk Menampilkan Texture pada AndEngine

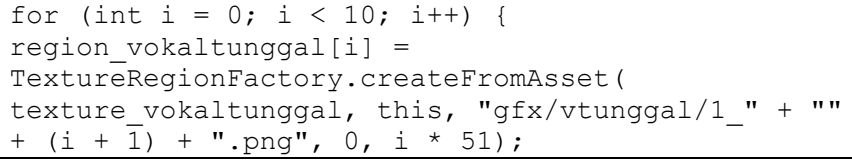

\section{Kode 2. Penggalan Kode Program untuk Pemanggilan File Audio}

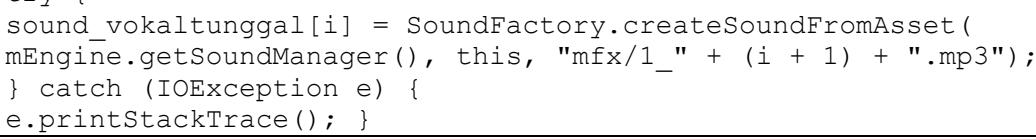

Menu kedua yaitu materi Batchim, berisi tentang huruf-huruf konsonan bahasa Korea yang dapat menjadi konsonan akhir khusus dan disertai contoh penggunaan batchim pada sebuah kata. Ada tujuh macam batchim yaitu batchim ' $k$ ', batchim 'n', batchim 't', batchim 'l', batchim ' $m$ ', batchim 'p', dan batchim 'ng'. Batchim ' $k$ ' memiliki tiga contoh kata yaitu hakkyo, bak, dan bueok. Batchim 'n' memiliki dua contoh yaitu ban dan insa. Batchim 't' memiliki tujuh contoh yaitu datta, keut, ot, itta, neutta, kot, dan hieut. Batchim ' '1' memiliki dua contoh yaitu gyosil dan chilpan. Batchim ' $\mathrm{m}$ ' memiliki tiga contoh yaitu bom, ireum, dan eomma. Batchim ' $p$ ' memiliki dua contoh yaitu bibimbap dan yeop. Batchim 'ng' memiliki dua contoh yaitu gabang dan hwajangsil. Tampilan tersebut dapat dilihat pada Gambar 8.

Menu ketiga yaitu materi Batchim Gabungan, berisi tentang batchim yang terdiri dari dua huruf konsonan. Ada dua macam batchim gabungan, yaitu konsonan depan yang dibaca dan konsonan akhir yang dibaca. Beberapa contoh batchim gabungan konsonan depan yang dibaca yaitu tulisan 'moks' dibaca 'mok', tulisan 'anjta' dibaca 'anta', tulisan 'neolpta' dibaca 'neolta', tulisan 'gols' dibaca 'gol', dan sebagainya. Beberapa contoh batchim gabungan konsonan akhir yang dibaca yaitu tulisan 'dark' dibaca 'dak', tulisan 'barpta' dibaca 'bapta', tulisan 'jeormda' dibaca 'jeomda', dan sebagainya. Tampilan tersebut dapat dilihat pada Gambar 9. 


\subsection{Halaman Mini Game}

Menu terakhir yaitu menu Play. Menu ini digunakan untuk memainkan mini game berupa kuis untuk menguji kemampuan user dalam mempelajari ketiga materi yang ada pada aplikasi ini. Dalam mini game ini, user akan menjawab soal berupa tulisan Hangeul yang dimunculkan secara acak dan ada tiga pilihan jawaban berupa cara membaca tulisan Hangeul tersebut. Cara menjawab soal tersebut adalah menggunakan teknik accelerometer. Salah satu kelebihan AndEngine adalah dengan adanya teknik accelerometer tersebut. Dengan adanya teknik accelerometer ini dapat menghasilkan permainan menarik yang membutuhkan gerakan dari device.

Cara memainkan mini game ini adalah dengan menggerakan device ke kanan atau ke kiri untuk memilih salah satu pilihan jawaban. Apabila jawaban benar akan lanjut ke soal berikutnya dan score bertambah. Tampilan mini game ini dapat dilihat pada Gambar 10.

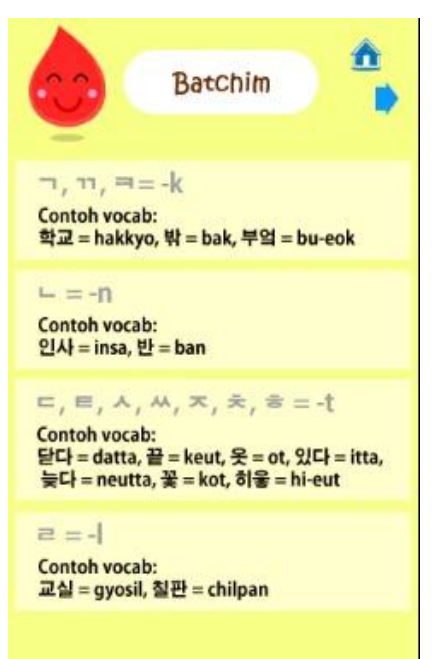

Gambar 8. Antarmuka Isi Materi Batchim

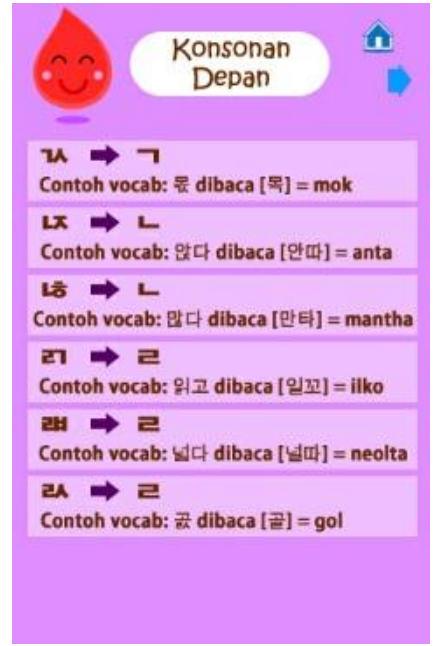

Gambar 9. Antarmuka Isi Materi Batchim Gabungan

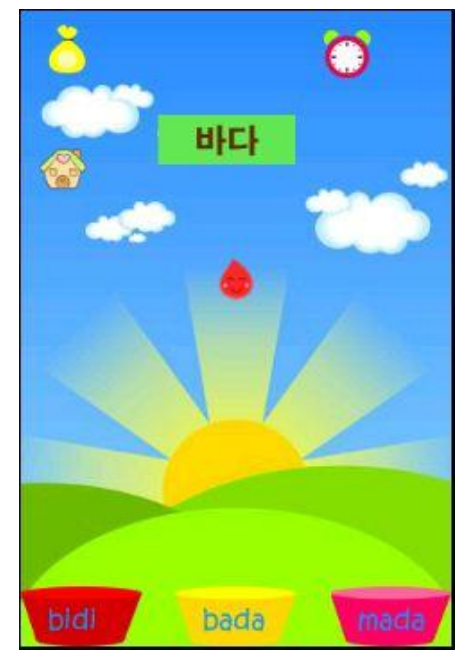

Gambar 10. Antarmuka Mini

Game

Kode 3 memperlihatkan bahwa Accelerometer pada AndEngine diaktifkan pada class onLoadScene() yaitu dengan memilih TYPE_ACCELEROMETER pada sensorManager. Kemudian, kecepatan gambar atau texture bergerak diatur pada class updateSpritePosition().

Kode 3. Penggalan Kode Program untuk Mengaktifkan Accelerometer pada AndEngine

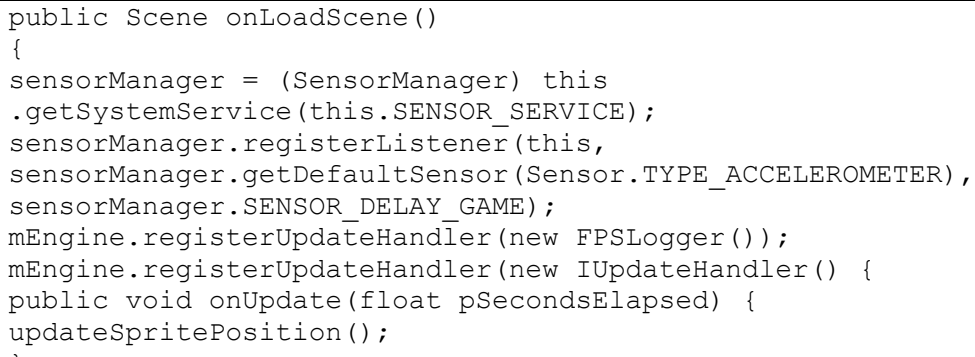

\section{Pengujian Aplikasi}

Pengujian aplikasi dilakukan dengan menguji fungsi-fungsi dari aplikasi yang telah dibuat untuk mencari kesalahan/bug pada sistem. Pengujian aplikasi dilakukan agar sistem yang dibuat berjalan sesuai dengan yang diharapkan dan dapat memenuhi kebutuhan pengguna. Pengujian aplikasi ini menggunakan dua teknik pengujian yaitu pengujian alpha dan pengujian beta. 


\subsection{Pengujian Alpha}

Pengujian alpha pada aplikasi pembelajaran dasar bahasa Korea ini dilakukan pada fitur Accelerometer yang digunakan pada mini game. Pengujian dilakukan dengan memainkan mini game, yaitu dengan menggerakkan device ke kiri dan kanan untuk mengatur gerakan obyek di layar seperti terlihat pada Gambar 10. Pengujian fitur Accelerometer pada mini game ini dilakukan untuk memastikan bahwa gerakan yang dilakukan pada device dapat selaras dengan gerakan obyek pada mini game. Hasil pengujian fitur Accelerometer ditunjukkan pada Tabel 1, sedangkan untuk mendeteksi dan mengatur gerakan ditunjukkan pada Kode 4.

Tabel 1. Tabel Hasil Pengujian Accelerometer

\begin{tabular}{cccc}
\hline No & Gerakan Device & Gerakan Obyek pada Mini Game & Hasil \\
\hline 1 & Digerakkan ke kanan & Obyek pada mini game ikut bergerak ke kanan & Valid \\
\hline 2 & Digerakkan ke kiri & Obyek pada mini game ikut bergerak ke kini & Valid \\
\hline
\end{tabular}

Kode 4. Penggalan Kode Program untuk Pengaturan Gerakan

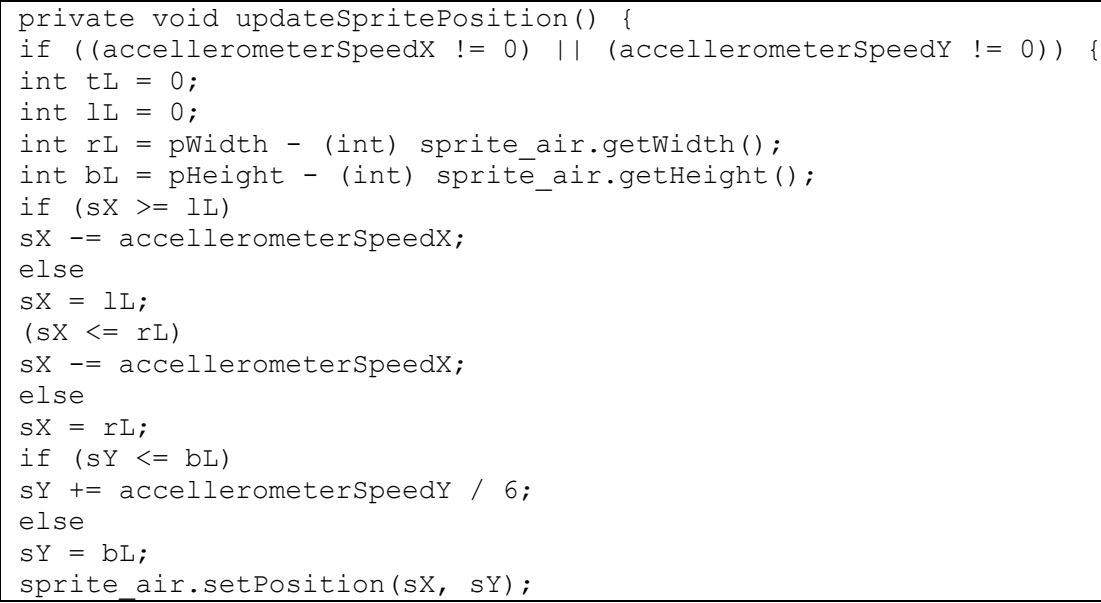

Penggalan kode pada Kode 4 berisi penjelasan class updateSpritePosition() untuk Accelerometer pada AndEngine. Class ini digunakan untuk mengatur gerakan gambar atau texture ke kanan, kiri, dan bawah. Variabel tL adalah untuk batas atas, variabel $\mathrm{lL}$ untuk batas bawah, variabel rL untuk batas kanan, dan variabel bL untuk batas bawah. Pada class ini juga dilakukan pengaturan kecepatan gerakan gambar atau texture.

\subsection{Pengujian Beta}

Pengujian beta sistem pada media pembelajaran dasar bahasa Korea ini, dilakukan terhadap sasaran pengguna dalam hal ini adalah responden dengan usia 12 tahun ke atas. Responden diambil dari murid-murid dari beberapa tempat kursus bahasa Korea di kota Salatiga dan Semarang. Kelompok pengujian beta tidak menyertakan orang-orang yang terlibat dalam pembuatan aplikasi. Jumlah responden yang mengikuti pengujian adalah 40 orang. Pengujian ini dilakukan dengan cara memberikan dua kali tes berupa soal-soal tentang huruf Hangeul. Tes dilakukan sebelum dan sesudah menggunakan aplikasi untuk mengetahui sejauh mana aplikasi ini dapat membantu pengguna dalam mempelajari dasar bahasa Korea. Hasil dari kedua tes menunjukkan bahwa nilai hasil tes setelah menggunakan aplikasi ini lebih tinggi dibandingkan dengan sebelum menggunakan aplikasi. Hal ini dapat dilihat pada Tabel 2.

Tabel 2. Tabel Perbandingan Nilai Tes Sebelum dan Sesudah Menggunakan Aplikasi

\begin{tabular}{ccc}
\hline Range Nilai & $\begin{array}{c}\text { Sebelum Menggunakan Aplikasi } \\
\text { Media Pembelajaran (Orang) }\end{array}$ & $\begin{array}{c}\text { Setelah Menggunakan Aplikasi } \\
\text { Media Pembelajaran (Orang) }\end{array}$ \\
\hline$<60$ & 12 & 0 \\
\hline $61-70$ & 10 & 2 \\
\hline $71-80$ & 9 & 11 \\
\hline $81-90$ & 4 & 14 \\
\hline $91-100$ & 5 &
\end{tabular}


Pengujian berikutnya dilakukan dengan membagikan kuisioner kepada 40 orang tersebut. Kuisioner ini berisi empat kategori pertanyaan seputar aplikasi yang telah dibuat. Pada kategori pertama yaitu sebanyak 92,5\% responden menjawab bahwa media pembelajaran dasar bahasa Korea ini mudah digunakan. Pada kategori kedua yaitu sebanyak 85\% responden berpendapat bahwa aplikasi ini membantu dalam mempelajari materi dasar bahasa Korea. Pada kategori ketiga yaitu sebanyak $75 \%$ responden berpendapat bahwa fitur mini game pada aplikasi ini membantu dalam menguji kemampuan responden dalam mempelajari materi. Pada kategori keempat yaitu sebanyak $87,5 \%$ responden berpendapat bahwa tampilan-tampilan dari media pembelajaran dasar bahasa Korea ini sudah menarik.

\section{Kesimpulan}

Berdasarkan hasil pembahasan sebelumnya, maka dapat disimpulkan bahwa penggunaan Accelerometer dari library AndEngine pada fitur mini game dapat berjalan dengan baik. Hasil pengujian alpha menunjukkan bahwa gerakan obyek pada mini game dapat selaras dengan gerakan device. Aplikasi ini juga bermanfaat bagi pengguna dalam mempelajari dasar bahasa Korea. Hal ini ditunjukkan dari pengujian beta yang menjelaskan bahwa setelah menggunakan aplikasi ini, pengguna menjadi lebih paham tentang materi dasar bahasa Korea. Pengguna juga merasa tertarik untuk belajar karena aplikasi ini dibuat dengan tampilan yang baik dan terdapat fitur mini game di dalamnya.

\section{Referensi}

Anam, M. A. K., Winarti, T., \& Vydia, V. 2013. Aplikasi Kamus Indonesia-Korea Untuk Percakapan Sehari-Hari Berbasis Android. Jurnal Trans IT, I (1): pp.1-14.

Ardiansyah, \& Na'im, R. D. 2012. Pengembangan Aplikasi Mobile Web Percakapan Bahasa Korea Berbasis Lokasi Menggunakan Foursquare API . Kaunia, VIII ( 2): pp. 61-77.

Arifina, Bulkis Fadilah. 2011. Pembuatan Aplikasi Pengenalan Bahasa Korea untuk Pemula dengan Menggunakan Android Versi 2.2 (Froyo). Jurnal Ilmiah Informatika Komputer, (Online), (http://library.gunadarma.ac.id/, diakses tanggal 12 Desember 2012).

Damarullah, W., Hamzah, A., \& Lestari, U. 2013. Aplikasi Pengenalan dan Pembelajaran Bahasa Korea (Hangeul) Berbasis Android. Jurnal Script, I (1): pp.78-88.

Dewi \& Sani. 2010. 1 Jam Lancar Membaca, Menulis, \& Berbicara Bahasa Korea. Bandung: Penerbit Ruang Kata.

Gramlich, Nicolas. 2010. AndEngine Summary, (Online), (https://github.com/nicolasgramlich/AndEngine/, diakses 17 September 2012).

Maghfiroh, Ana. 2013. Model Pembelajaran Bahasa Asing Oleh Eks-Tenaga Kerja Indonesia Korea di Lembaga Pendidikan Bahasa Korea Sarangheo. Jurnal Universitas Muhammadiah, I (1): pp.1-9.

Septiawan, A.N., \& Setiadi, T. 2013. Aplikasi Pengenalan Huruf Hangeul Berbasis Multimedia Interaktif. Jurnal Sarjana Teknik Informatika, I(1): 347-357.

Sutrisno, A., \& Istiyanto, J.E. 2009. Perpektif \& Tangangan Pengembangan M-Learning. Jurnal Informatika, $\mathrm{V}(1)$ : pp.87-96.

Triyanto, E., Anitah, S., \& Suryani, N. 2013. Peran Kepimpinan Kepala Sekolah Dalam Pemanfaatan Media Pembelajaran Sebagai Upaya Peningkatan Kualitas Proses Pembelajaran. Jurnal Teknologi Pendidikan, I (2): pp.226-238.

Zamroni, M.S., Suryaman, N., \& Jalaluddin, A. 2013. Rancang Bangun Aplikasi Permainan Untuk Pembelajaran Anak Menggunakan HTML5. Jurnal Teknika, V (2): pp. 489-493. 